\title{
Effects of gamma irradiation treatments and storage durations on fatty acid composition of natural hazelnut kernels*
}

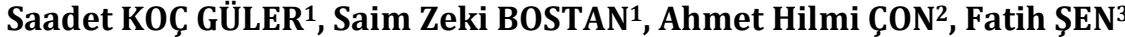

\author{
10rdu University, Faculty of Agriculture, Department of Horticulture, ORDU \\ ${ }^{2}$ Ondokuz Mayıs University, Faculty of Engineering, Department of Food Engineering, SAMSUN \\ ${ }^{3}$ Ege University, Faculty of Agriculture, Department of Horticulture, İZMİR
}

\begin{abstract}
*The present study was supported by Industrial Theses Support Program (SAN-TEZ) of General Directorate of Science and Technology of the Ministry of Science, Industry and Technology with a project number of 01357.2012-1. Current study presented partial outcomes of Ph.D. thesis of Saadet KOÇ GÜLER. The study presented as a poster at VII. Bahçe Ürünlerinde Muhafaza ve Pazarlama Sempozyumu in Eğirdir, Isparta.
\end{abstract}

Alınıș tarihi: 3 Nisan 2017, Kabul tarihi: 20 Aralık 2017

Sorumlu yazar: Saadet KOÇ GÜLER, e-posta: saadet.koc@gmail.com

\begin{abstract}
In this study, vacuum packed natural hazelnut kernels were subjected to gamma irradiation treatments at $0.5,1$ and $1.5 \mathrm{kGy}$ doses. Irradiated and non-irradiated hazelnut kernels were stored at $20^{\circ} \mathrm{C}$ temperature and $55-60 \%$ relative humidity for 18 months. Fatty acid composition of samples was assessed right after irradiation and at 3, 6, 9, 12, 15 and $18^{\text {th }}$ month of storage duration. Results revealed that irradiation doses did not significantly influence fatty acid composition of hazelnut kernels ( $p>0.05)$, but storage durations significantly influenced fatty acid composition $(\mathrm{p}<0.05)$.
\end{abstract}

Anahtar kelimeler: Hazelnut, gamma irradiation, storage, fatty acid

Natürel iç findıkta gama ışını uygulamalarının depolama süresince yağ asitleri kompozisyonuna etkisi

Öz

Çalışmada, vakumlu olarak paketlenmiş olan natürel iç findıklara $0.5,1$ ve 1.5 kGy dozlarda gama ışını uygulanmıştır. Işınlanmış ve ışınlanmamış iç findıklar $20^{\circ} \mathrm{C}$ sıcaklık ve \% 55-60 nemde 18 ay boyunca depolanmıștır. Örneklerin yă̆ asidi kompozisyonu işınlamadan hemen sonra ve depolamanın $3,6,9,12,15$ ve 18 . aylarında değerlendirilmiştir. Sonuçlar, uygulanan gama ışını dozlarının iç fındıklarda yağ asidi kompozisyonunu etkilemediğini göstermiştir ( $p>0.05)$. Ancak depolama süresi, yă asidi kompozisyonunu etkilemiştir $(\mathrm{p}<0.05)$

Key words: Fındık, gama ışını, depolama, yağ asitleri

\section{Introduction}

Hazelnut is a cultivar of Fagales order. It belongs to Coryleae sub-genus of Betulaceae family. The genus name is Corylus (Özçağıran et al., 2014). Hazelnut is a quite significant product for Turkish economy. Turkey is the leading hazelnut producer worldwide. Each year, Turkey produces about 600000 tons inshell nuts and exports about $70 \%$ of this production mostly as natural hazelnut kernels. Annual export revenue is around 1.3 billion dollars (Anonymous, 2017). Hazelnut is commonly used as snack food mostly as roasted (either inshell or kernel); blanched, chopped, sliced, grinded hazelnuts and hazelnut meals are used in chocolate, cookie and confectionery industries, also used in sweets, cakes, ice cream, in salad dressing. Hazelnut oil, pressed from hazelnuts, is strongly flavored and used as cooking oil (Köksal et al., 2006; Özçağıran et al., 2014; Anonymous, 2016b). 
Hazelnut is quite rich in nutrients. It includes about $55-71 \%$ oil and majority of oil is composed of unsaturated fatty acids (about 85-90\%). Oleic acid is the major component of unsaturated fatty acids (74.9-84.3\%) (Botta et al., 1994; Köksal et al., 2006; Kanbur et al., 2013; Rezaei et al., 2014). Among the other nuts, hazelnut has the greatest oleic content. With regard to oleic acid, hazelnut is followed by pistachio (75\%) (Al-Bachir, 2015), almond (50.4181.2\%) (Askin et al., 2007), cashew nut (49.08\%) (Mexis and Kontominas, 2009a), chestnut (41\%) (Morrone et al., 2015) and walnut (14.92-20.22\%) (Pereira et al., 2008).

Although irradiation is a quite old process, it has recently been used in agricultural products. The processes is now widely used since it is easy to operate, conveniently be used over packed goods, does not leave any chemical residues, does not get in direct contact with the product, does not create a resistance mechanism in pests, does not make the product radioactive.

In Turkey, Food Irradiation Regulation was issued in 1999. Hazelnut was included in 3rd Group food stuff in this regulation. According to regulation, irradiation can be applied to food stuff in this group up to a dose of $1 \mathrm{kGy}$ to prevent infestation and up to $5 \mathrm{kGy}$ to reduce microorganisms or to prolong shelf life.

There are several studies carried out worldwide about irradiation treatments in nuts (Al-Bachir, 2004; Bhattacharjee et al., 2003; Bingöl et al., 2011; Bogunovic et al., 1993; Antonio et al., 2011; Fernandes et al., 2011a; Fernandes et al., 2011b; Mexis and Kontominas, 2009a; Mexis and Kontominas, 2009b; Sanchez-Bel et al., 2008; Ozyardimci et al., 2006; Gecgel et al., 2011; Dogan et al., 2007). Different irradiation sources and doses were used in these studies and several quality parameters of nuts were assessed.

Number of studies investigating the effects of gamma irradiation on fatty acids of hazelnuts is quite limited (Mexis and Kontominas, 2009b; Geçgel et al., 2011). In those studies, only the post-treatment changes were assessed. The studies assessing irradiation and storage treatments together are scarcely any. The only study assessing quality parameters of gammairradiated hazelnuts throughout the storage was carried out by Koç Güler et al. (2017).
A study investigating the changes encountered in fatty acids of gamma-irradiated natural hazelnut kernel throughout the storage was not come across. It is quite unfortunate not to have such a study on hazelnut with quite rich oil content majority of which composed of unsaturated fatty acids. Gamma irradiation is used as an alternative to chemical treatments and hazelnut kernels have quite long storage durations. Polyunsaturated fatty acids are highly affected by irradiation (Çetinkaya et al., 2010). Therefore, it is considered important to examine the changes in the fatty acids of gammairradiated hazelnuts during the storage period. The present study is the first and the only study investigating the changes in fatty acid composition of gamma-irradiated natural hazelnut kernels throughout 18-month storage duration.

In present study, natural hazelnut kernels were subjected to gamma irradiation at $0.5,1$ and $1.5 \mathrm{kGy}$ doses and stored at $20^{\circ} \mathrm{C}$ and $55-60 \%$ relative humidity for 18 months. Then, the changes in fatty acid composition of irradiated kernels were investigated.

\section{Material and Method \\ Hazelnut samples}

The natural nut kernels of the year 2012 were used as the experimental material of this study. Materials were purchased from "Gürsoy Agricultural Products Food Industry and Trade Co." operating in Ordu province. Materials were of levant quality group coming from the coastline of Ordu locality. Experimental materials were supplied as they were used in the company, in other words without any cultivar selection. The kernel diameter range was 9$15 \mathrm{~mm}$.

The hazelnut kernels used in this study were placed and vacuumed in polyethylene bags as to have $200 \mathrm{~g}$ in each bag and they were not subjected to any disinfection or disinfestation processes. The specifications for polyethylene bags were supplied from the company and presented in Table 1. Vacuumed packs were then placed in parcels and sent to "Gamma Pak Sterilization Industry and Trade Co." operating in Tekirdağ Çerkezköy. Samples were subjected to gamma irradiation treatments using 60Co irradiator (MDS Nordion, Canada) at 0.5, 1 and $1.5 \mathrm{kGy}$ doses. Absorbed doses were monitored with a Harwell Amber Perspex dosimeter. 
Table 1. Specifications for polyethylene bags

\begin{tabular}{cc}
\hline Specifications & Unit \\
\hline Thickness & $150 \pm 8 \mu \mathrm{m}$ \\
Oxygen permeability $\left(23^{\circ} \mathrm{C}\right.$ dry) & $20 \mathrm{cc} / \mathrm{m}^{2} /$ day \\
Water vapor permeability $\left(38^{\circ} \mathrm{C}, 90 \%\right.$ relative humidy) & $5 \mathrm{~g} / \mathrm{m}^{2} /$ day \\
\hline
\end{tabular}

Irradiated samples coming from Gamma Pak were subjected to initial fatty acid composition analyses before to place them into storages. Analyzed samples were then stored at $20^{\circ} \mathrm{C}$ and $55-60 \%$ relative humidity for 18 months. In storage, four sample groups were formed as of control (0 kGy), $0.5 \mathrm{kGy}, 1$ kGy and $1.5 \mathrm{kGy}$ irradiated in 3 replications. Analyses were performed in three-month intervals.

\section{Fatty Acid Composition}

Fatty acid rates (\%) were determined through reading cold-extracted phase in a gas chromatography device and interpreting the resultant graph.

Oil extraction was performed through cold extraction method not requiring heat treatment to prevent the distortion of fatty acids. In this method, initially $30 \mathrm{~g}$ grinded natural kernel sample was mixed with oil dissolvent hexane in a closed Erlenmeyer flask and shaken in a shaker (IKA labortechnik K5501 digital) for two hours at a high speed (about $280 \mathrm{rpm}$ ). Following this process, the sample oil turned into a solution with hexane and resultant solution was filtered through glass-wool into a beaker. The solvent was removed from the solution and crude oil was then obtained (Başoğlu, 1987).

Before fatty acid analyses, crude oil samples were subjected to esterification process (Anonymous, 2000 ). In this process, $0.5 \mathrm{~g}$ crude oil was placed into $10 \mathrm{ml} \mathrm{screw}$-cap test tube and the samples were supplemented with $1 \mathrm{ml} 2 \mathrm{~N}$ methanolic $\mathrm{KOH}$ solution and $7 \mathrm{ml} \mathrm{n}$-Hexane and resultant mixture was centrifuged at $7000 \mathrm{rpm}$ for 30 minutes. In this way, upper phase was clarified. The upper phase including fatty acid metal esters was placed into special glass bottles before mixed into the other phase and made ready for injection into gas chromatography (Agilent Technologies 6890N, CA, USA). With an automatic sampling apparatus (HP7683 B), $1 \mu$ l gas sample was taken and injected into the device. Analysis was carried out by using 60 m-long "Spelco 2380" brand capillary column $(60 \mathrm{~m}$ x $0.25 \mathrm{~mm}$ i.d., $0.20 \mu \mathrm{m}$ film thickness; Supelco, Bellefonte, PA, USA). Resultant peaks were identified with the aid of fatty acid standard (SupelcoTM 37 Component FAME mix, Supelco, Bellefonte, PA, USA). Peak times and areas were calculated and fractions were determined and expressed in \% fatty acid.

\section{Experimental Design and Statistical Analyses}

Experiments were conducted in randomized plots experimental design with 3 replications. Dose factor was composed of 4 levels as of control, $0.5 \mathrm{kGy}, 1$ $\mathrm{kGy}$ and $1.5 \mathrm{kGy}$ and storage function was composed of 7 levels as of initial, 3, 6, 9, 12, 15 and 18 months. Data normality was checked with Anderson-Darling test and variance homogeneity was checked with Levene test. The data complying with the relevant assumptions were subjected to two-way ANOVA test and different means were tested with Tukey's multiple comparison test at 5\% level. Statistical analyses were carried out with Minitab 17 statistical software.

\section{Results and Discussion}

While the effects of different irradiation doses on palmitic acid (C16:0), palmitoleic acid (C16:1), stearic acid (C18:0), oleic acid (C18:1), linoleic acid (C18:2), linolenic acid (C18:3), total polyunsaturated fatty acids (TPUFA), total unsaturated fatty acids (TUFA), total monounsaturated fatty acids (TMUFA) were not found to be significant, the difference in storage duration factor levels were found to be significant $(p<0.05)$. Tukey's test results are provided in Table 2.

With regard to total saturated fatty acids (TSFA), irradiation doses, storage durations and dose $\mathrm{x}$ storage interaction were not found to be significant $(\mathrm{p}>0.05)$.

There were fluctuating changes (either increasing or decreasing) in fatty acids throughout the storage duration (Table 2). However, except for palmitoleic acid and linolenic acid, the changes in other fatty acids between the beginning and the end of storage were not significant. 
Table 2. Changes in fatty acids throughout the storage period

\begin{tabular}{|c|c|c|c|c|c|c|c|c|}
\hline \multirow{2}{*}{ Fatty Acids } & \multicolumn{7}{|c|}{ Storage Duration (Month) } & \multirow{2}{*}{$\mathrm{p}$} \\
\hline & 0 & 3 & 6 & 9 & 12 & 15 & 18 & \\
\hline PA & $\begin{array}{c}5.692 \pm 0.034 \\
\mathrm{AB}\end{array}$ & $\begin{array}{c}5.661 \pm 0.046 \\
\text { B }\end{array}$ & $\begin{array}{c}5.743 \pm 0.050 \\
\mathrm{AB}\end{array}$ & $\begin{array}{c}5.835 \pm 0.035 \\
\mathrm{AB}\end{array}$ & $\begin{array}{c}5.802 \pm 0.037 \\
\mathrm{AB}\end{array}$ & $\begin{array}{c}5.832 \pm 0.075 \\
\mathrm{AB}\end{array}$ & $\begin{array}{c}5.890 \pm 0.049 \\
\mathrm{~A}\end{array}$ & 0.023 \\
\hline SA & $\begin{array}{c}2.570 \pm 0.024 \\
\mathrm{AB}\end{array}$ & $\begin{array}{c}2.533 \pm 0.044 \\
\mathrm{AB} \\
\end{array}$ & $\begin{array}{c}2.542 \pm 0.025 \\
\mathrm{AB} \\
\end{array}$ & $\begin{array}{c}2.646 \pm 0.035 \\
\mathrm{~A} \\
\end{array}$ & $\begin{array}{c}2.468 \pm 0.034 \\
\text { B }\end{array}$ & $\begin{array}{c}2.561 \pm 0.027 \\
\mathrm{AB}\end{array}$ & $\begin{array}{c}2.572 \pm 0.038 \\
\mathrm{AB} \\
\end{array}$ & 0.042 \\
\hline TSFA & $8.275 \pm 0.039$ & $8.272 \pm 0.084$ & $8.335 \pm 0.065$ & $8.528 \pm 0.056$ & $8.342 \pm 0.060$ & $8.423 \pm 0.079$ & $8.461 \pm 0.075$ & 0.090 \\
\hline PTA & $\begin{array}{c}0.128 \pm 0.022 \\
\text { B }\end{array}$ & $\begin{array}{c}0.170 \pm 0.003 \\
\mathrm{~A}\end{array}$ & $\begin{array}{c}0.171 \pm 0.003 \\
\mathrm{~A}\end{array}$ & $\begin{array}{c}0.172 \pm 0.002 \\
\mathrm{~A}\end{array}$ & $\begin{array}{c}0.179 \pm 0.002 \\
\mathrm{~A}\end{array}$ & $\begin{array}{c}0.172 \pm 0.005 \\
\mathrm{~A}\end{array}$ & $\begin{array}{c}0.172 \pm 0.004 \\
\mathrm{~A}\end{array}$ & 0.012 \\
\hline $\mathrm{OA}$ & $\begin{array}{c}83.734 \pm 0.220 \\
\mathrm{AB} \\
\end{array}$ & $\begin{array}{c}83.951 \pm 0.172 \\
\mathrm{AB} \\
\end{array}$ & $\begin{array}{c}83.812 \pm 0.103 \\
\mathrm{AB} \\
\end{array}$ & $\begin{array}{c}84.084 \pm 0.082 \\
\mathrm{~A} \\
\end{array}$ & $\begin{array}{c}83.026 \pm 0.141 \\
C\end{array}$ & $\begin{array}{c}83.370 \pm 0.174 \\
\text { BC } \\
\end{array}$ & $\begin{array}{c}83.343 \pm 0.144 \\
\text { BC } \\
\end{array}$ & 0.000 \\
\hline TMUFA & $\begin{array}{c}83.965 \pm 0.198 \\
\text { ABC }\end{array}$ & $\begin{array}{c}84.261 \pm 0.169 \\
\text { AB }\end{array}$ & $\begin{array}{c}84.136 \pm 0.103 \\
A B\end{array}$ & $\begin{array}{c}84.404 \pm 0.083 \\
\mathrm{~A}\end{array}$ & $\begin{array}{c}83.349 \pm 0.141 \\
\text { C }\end{array}$ & $\begin{array}{c}83.701 \pm 0.173 \\
\mathrm{BC}\end{array}$ & $\begin{array}{c}83.674 \pm 0.142 \\
\text { BC }\end{array}$ & 0.000 \\
\hline LA & $\begin{array}{c}7.680 \pm 0.188 \\
\mathrm{AB} \\
\end{array}$ & $\begin{array}{c}7.350 \pm 0.159 \\
\text { BC } \\
\end{array}$ & $\begin{array}{c}7.361 \pm 0.099 \\
\text { BC } \\
\end{array}$ & $\begin{array}{c}6.858 \pm 0.114 \\
\text { C } \\
\end{array}$ & $\begin{array}{c}8.172 \pm 0.118 \\
\mathrm{~A} \\
\end{array}$ & $\begin{array}{c}7.749 \pm 0.163 \\
\mathrm{AB} \\
\end{array}$ & $\begin{array}{c}7.739 \pm 0.156 \\
\mathrm{AB} \\
\end{array}$ & 0.000 \\
\hline LNA & $\begin{array}{c}0.079 \pm 0.020 \\
B\end{array}$ & $\begin{array}{c}0.117 \pm 0.00 \\
2 \mathrm{~A}\end{array}$ & $\begin{array}{c}0.123 \pm 0.002 \\
\mathrm{~A}\end{array}$ & $\begin{array}{c}0.123 \pm 0.00 \\
2 \mathrm{~A}\end{array}$ & $\begin{array}{c}0.115 \pm 0.002 \\
\mathrm{~A}\end{array}$ & $\begin{array}{c}0.127 \pm 0.004 \\
\mathrm{~A}\end{array}$ & $\begin{array}{c}0.126 \pm 0.003 \\
\mathrm{~A}\end{array}$ & 0.002 \\
\hline TPUFA & $\begin{array}{c}7.760 \pm 0.191 \\
\mathrm{AB} \\
\end{array}$ & $\begin{array}{c}7.467 \pm 0.159 \\
\text { BC } \\
\end{array}$ & $\begin{array}{c}7.484 \pm 0.098 \\
\text { BC } \\
\end{array}$ & $\begin{array}{c}6.981 \pm 0.114 \\
\text { C } \\
\end{array}$ & $\begin{array}{c}8.288 \pm 0.119 \\
\mathrm{~A} \\
\end{array}$ & $\begin{array}{c}7.876 \pm 0.163 \\
\mathrm{AB} \\
\end{array}$ & $\begin{array}{c}7.865 \pm 0.155 \\
\mathrm{AB} \\
\end{array}$ & 0.000 \\
\hline TUFA & $\begin{array}{c}91.725 \pm 0.039 \\
\mathrm{~A}\end{array}$ & $\begin{array}{c}91.728 \pm 0.084 \\
\text { A }\end{array}$ & $\begin{array}{c}91.620 \pm 0.070 \\
\mathrm{AB}\end{array}$ & $\begin{array}{c}91.385 \pm 0.071 \\
\text { B }\end{array}$ & $\begin{array}{c}91.636 \pm 0.060 \\
\mathrm{AB}\end{array}$ & $\begin{array}{c}91.577 \pm 0.079 \\
\mathrm{AB}\end{array}$ & $\begin{array}{c}91.539 \pm 0.075 \\
\mathrm{AB}\end{array}$ & 0.034 \\
\hline
\end{tabular}

Data were presented as mean \pm standard error. The difference in means indicated with different capital letter in the same row are significant $(\mathrm{p}<0.05)$. PA: Palmitic acid, SA: Stearic acid, PTA: Palmitoleic acid, OA: Oleic acid, LA: Linoleic acid, LNA: Linolenic acid

Irradiation treatments were applied to several nuts and most of them reported that irradiation treatments did not influence fatty acid composition (Lozoya, 2006; Sanchez-Bel et al., 2008; Bhatti et al., 2010; Antonio et al., 2012a; Di Stefano et al., 2014). On the other hand, irradiation stress may result in slight changes in fatty acid profile (Bhatti et al., 2013). There are some previous studies reporting decreasing mono and total unsaturated fatty acids and increasing total saturated fatty acids with increasing irradiation doses (Mexis and Kontominas, 2009b; Geçgel et al., 2011). Contrary to these studies, Fernandes et al. (2011b) indicated that saturated, monounsaturated and polyunsaturated fatty acids were not influenced by storage durations or irradiation treatments, but some special fatty acids (palmitic acid, oleic acid) were influenced from the relevant treatments. Similarly, Al-Bachir (2015) reported decreasing oleic acid, increasing linoleic acid and unchanged other fatty acids with irradiation treatments. Mexis and Kontominas (2009a) reported decreasing oleic acid concentrations and increasing stearic acid concentrations with increasing irradiation doses and also indicated that polyunsaturated fatty acids were not influenced by irradiation treatments. Barreira et al. (2012), in a study about fatty acids, reported varying lauric, palmitoleic and linolenic acid contents with irradiation doses, but concluded that saturated, mono and polyunsaturated fatty acids were not influenced by both storage durations and irradiation doses. Koyuncu (2004) carried out a study with shelled and kernel nut and reported increasing palmitic and oleic acid contents throughout the storage duration and identified linoleic acid contents as between 12.41-10.35\%.

\section{Conclusion}

The effects of gamma irradiation doses (Table 2) and dose $\mathrm{x}$ storage duration interaction on fatty acid composition of natural hazelnut kernels were not found to be significant ( $p>0.05)$. Irradiation stress may result in slight changes in fatty acid profile (Bahatti et al., 2013). However, it was indicated in several studies with nuts that irradiation treatments did not influence fatty acid composition of the kernels (Lozoya, 2006; Gölge and Ova, 2008; Sanchez- Bel et al., 2008; Bahatti et al., 2010; Antonio et al., 2012; Di Stefano et al., 2014). Foods containing lipids are particularly affected by 02 during irradiation and can develop off or rancid flavors (Urbain, 1986). For this reason, it can be considered that the use of vacuum packs in the study reduces the effect of irradiation on fatty acids.

Storage duration influenced fatty acid composition $(p<0.05)$ (Table 2). While the effects of storage 
durations on total unsaturated fatty acids were significant $(\mathrm{p}<0.05)$, effects on total saturated fatty acids were not found to be significant ( $p>0.05)$. However, the TUFA / TSFA ratio decreased at the end of storage period. Similar with the present findings, Koyuncu (2004), Koyuncu et al. (2005) and Ghirrardello et al. (2013) reported significant effects of storage durations on fatty acids.

\section{Acknowledgements}

The present study was supported by Industrial Theses Support Program (SAN-TEZ) of General Directorate of Science and Technology of the Ministry of Science, Industry and Technology with a project number of 01357.2012-1. Acknowledgements are extended to project partner "Gürsoy Agricultural Products Food Industry and Trade Co." and to Asst. Prof. Dr. Yeliz KAȘKO ARICI of Animal Science Department of Ordu University Agricultural Faculty for her supports provided in statistical analyses. Current study presented partial outcomes of Ph.D. thesis of Saadet KOÇ GÜLER.

\section{Kaynaklar}

Al-Bachir, M. 2004. Effect of gamma irradiation on fungal load, chemical and sensory characteristics of walnuts Uuglans regia L.), Journal of Stored Products Research, 40: 355-362.

Al-Bachir, M. 2015. Studies on the physicochemical characteristics of oil extracted from gamma irradiated pistachio (Pistacia vera L.), Food Chemistry, 167: 175-179.

Anonymous, 2000. Determination of fatty acid composition in olive oils: methylation methods (Paragraph 5 in 2.301 IUPAC Method "For Preparation of the Fatty Acids Methyl Esters" or Paragraph 4 in Commission Regulation CEE/72/77) International Olive Oil Council Analytical Methods.

Anonymous, 2017. Karadeniz Findık Mamülleri ve İhracatçlar Birliği.

Anonymous, 2016b. http://www.gursoy.com.tr/index.php option=com_virtuemart\&page=shop.browse\&category_id=15\&Itemid=263 (Accessed on 15.05.2015) .

Antonio, A.L., Fernandes, A., Barreira, J.C.M., Bento, A., Botelho, M.L., Ferreira, I.C.F.R. 2011. Influence of gamma irradiation in the antioxidant potential of chestnuts (Castanea sativa Mill.) fruits and skins, Food and Chemical Toxicology, 49: 1918-1923.

Antonio, A. L., Ramalhosa, E., Quintana, B., Botelho, M. L., Bento, A., Ferreira, I. C. F. R. 2012. Effects of gamma irradiation on physco-chemical parameters of chestnut fruits, 1st workshop on food irradiation in the Mediterranean region, 14-17 March, Thessaloniki, Greece. (Abstract)

Askin, M.A., Balta, M.F., Tekintas, F.E., Kazankaya, A., Balta, F. 2007. Fatty acid composition affected by kernel weight in almond [Prunus dulcis (Mill.) D.A. Webb.] genetic resources, Journal of Food Compositional and Analysis, 20: 7-12.

Barreira, J. C. M., Antonio, A. L., Günaydi, T., Alkan, H., Bento, A., Botelho, M. L., Ferreira, I. C. F. R. 2012. Chemometric characterization of gamma irradiated chestnuts from Turkey, Radiation Physics and Chemistry, 81: 1520-1524

Başoğlu, F., 1987. Bazı soya çeşitlerinde elde edilen ham yağların fiziksel ve kimyasal özelliklerinin belirlenmesi, Gıda dergisi, 12 (3): 151-156 (In Turkish)

Bhatti, I.A., Ashraf, S., Shadid, M., Asi, M.R., Mehboob, S. 2010. Quality index of oils extracted from $\gamma$ irradiated peanuts (Arachis hipogaea L.) of the golden and bari varieties, Applied Radiation and Isotopes, 68: 2197-2201

Bhatti, I.A., Iqbal, M., Anwar, F., Shadid, S.A., Shadid, M. 2013. Quality characteristics and microbiological safety evaluation of oils extracted from gamma irradiated almond (Prunus dulcis Mill.) seeds, Grasas Y Aceites, 64(1): 68-76.

Bhattacharjee, P., Singhal, R.S., Gholap, A.S., Variyar, P.S., Bongirwar, D.R. 2003. Compositional profiles of $\gamma$ irradiated cashew nuts, Food Chemistry, 80: 159163.

Bingol, G., Yang, J., Brandl, M.T., Pan, Z., Wang, H., McHugh, T.H. 2011. Infrared pasteurization of raw almonds, Journal of Food Engineering, 104: 387-393.

Bogunović, M., Katušin-Ražem B., Đurić-Bezmalinović S., Ražem, D., 1993. Chemical and Organoleptic Investigations of Hazelnut Irradiated with Multiple Disinfestation Doses, Prehrambeno Technol. Biotehnol. Rev. 31: 83-88.

Çetinkaya, N., Ünal, Z., Tükenmez, İ., İç, E., Denl, E., Güçlü, H., Halkman, H.B.D., Kozat, P., Başbayraktar, V., Özyardımcı, B., Uygun Sarıbay, M., Köseoğlu, T., Özvatan, S., Erçin, D., Yazıcı, N., Erel, Y., 2010. Gıda Işınlama, Türkiye Atom Enerjisi Kurumu.

Botta, R., Gianotti, C., Richardson, D., Suwanagul, A., Sanz, C.L., 1994. Hazelnut variety organic acids, sugars and total lipid fatty acids. III. International Congress on Hazelnut, Alba, Italy, September 14-18, Acta Horticulture 351, 693-699.

Di Stefano, V., Pitonzo, R., Bartolotta, A., D’Oca, M.C. 2014 Effects of $\gamma$-irradiation on the $\alpha$-tocopherol and fatty acid content of raw unpeeled almond kernels 
(Prunus dulcis), LTW- Food Science and Technology, 59: 572-576.

Dogan, A., Siyakus, G., Severcan, F. 2007. FTIR spectroscopic characterization of irradiated hazelnut (Corylus avellana L.), Food Chemistry, 100: 1106-1114.

Fernandes, A., Barreira, C.J.M., Antonio, A.L., Bento, A., Botelho, M.L., Ferreira, I.C.F.R. 2011a. Assessing the effects of gamma irradiation and storage time in energetic value and in major individual nutrients of chestnuts, Food and Chemical Toxicology, 49 (9): 2429-2432.

Fernandes, A., Antonio, A., Barros, L., Barreira, J. C. M., Bento, A., Botelho, M. L., Ferreira, I. C. F. R. 2011b. Low dose $\gamma$-irradiation as a suitable solution for chestnut (Castanea sativa Miller) conservation: effects on sugars, fatty acids and tocopherols, Journal of Agricultural and Food Chemistry, 59 (18): 10028-10033.

Gecgel, U., Gumus, T., Tasan, M., Daglioglu, O., Arici, M. 2011. Determination of fatty acid composition of $\gamma$ irradiated hazelnuts, walnuts, almonds and pistachios, Radiation Physics and Chemistry, 80: 578-581.

Ghirardello, D., Contessa, C., Valentini, N., Zeppa, G., Rolle, L., Gerbi, V., Botta, R. 2013. Effect of storage conditions on chemical and physical characteristics of hazelnut (Corylus avellana L.), Postharvest Biology and Technology, 81: 37-43.

Gölge, E., Ova, G. 2008. The effects of food irradiation on quality of pine nut kernels, Radiation Physics and Chemistry, 77: 365-369.

Kanbur, G., Arslan, D., Özcan, M.M., 2013. Some compositional and physical characteristics of some Turkish hazelnut (Corylus avellana L.) variety fruits and their corresponding oils. International Food Research Journal, 20(5): 2161-2165.

Koç Güler, S., Bostan, S.Z., Çon, A.H., 2017. Effects of gamma irradiation on chemical and sensory characteristics of natural hazelnut kernels. Postharvest Biology and Technology, 123, 12-21.

Koyuncu M.A., 2004. Change of fat content and fatty acid composition of Turkish hazelnuts (Corylus avellana L.) during the storage. Journal of Food Quality, 27, 304-309.

Koyuncu, M.A., Islam, A., Küçük, M. 2005. Fat and fatty acid composition of hazelnut kernels in vacuum packages during storage. Grasas y Aceites, 56(4): 263-266.
Köksal, A.İ., Artik, N., Şimşek, A., Güneş, N., 2006. Nutrient composition of hazelnut (Corylus avellana L.) varieties cultivated in Turkey. Food Chemistry, 99: 509-515.

Lozoya, J. E. V. 2006. Cultivar and e-beam irradiation effects on phytochemical content and antioxidant properties of pecan kernels. Master of Science Thesis, Texas A\&M University, Texas, $69 \mathrm{p}$.

Mexis, S.F., Kontominas, M.G. 2009a. Effect of $\gamma$ irradiation on the physicochemical and sensory properties of cashew nuts (Anacardium occidentale L.), LWTFood Science and Technology, 42: 1501-1507.

Mexis, S.F., Kontominas, M.G. 2009b. Effect of $\gamma$ irradiation on the physicochemical and sensory properties of hazelnut (Corylus avellana L.), LWT- Food Science and Technology, 78: 407-413.

Morrone, L., Dall'Asta, C., Silvanini, A., Cirlini, M., Beghe, D., Fabbri, A., Ganino, T., 2015. The influence of seasonality on total fat and fatty acid profile, protein and amino acid, and antioxidant properties of traditional Italian flours from different chestnut cultivars, Scientia Horticulturae, 192: 132-140.

Ozyardimci, B., Cetinkaya, N., Denli, E., Ic, E., Alabay, M. 2006. Inhibition of egg and larval development of the Indian meal moth Plodia interpunctella (Hübner) and almond moth Ephestia cautella (Walker) by gamma radiation in decorticated hazelnuts, Journal of Stored Products Research, 42: 183-196.

Özçağıran, R., Ünal, A., Özeker, E., İsfendiyaroğlu, M., 2014. Ilıman İklim Meyve Türleri: Sert Kabuklu Meyveler, Cilt 3, Ege Üniversitesi Yayınları Ziraat Fakültesi Yayını: 566. Ege Üniversitesi Basımevi, Bornova, İzmir, 262 p (In Turkish).

Pereira, J.A., Oliveira, I., Sousa, A., Ferreira, I.C.F.R., Bento, A., Estevinho, L., 2008. Bioactive properties and chemical composition of six walnut Uuglans regia L.) cultivars, 46: 2103-2111.

Rezaei, F., Bakhshi, D., Ghazvini, R.F., Majd, D.J., Pourghayoumi, M., 2014. Evaluation of fatty acid content and nutritional properties of selected native and imported hazelnut (Corylus avellana L.) varieties grown in Iran. Journal of Applied Botany and Food Quality, 87: 104-107.

Sanchez-Bel, P., Egea, I., Romojaro, F., Martinez-Madrid, M.C. 2008. Sensorial and chemical quality of electron beam irradiated almonds (Prunus amygdalus), LWT, 41: 442-449.

Urbain, W.M., 1986. Food İrradiation, Food Science and Technology, A Series of Monographs, Academic Press, Orlando, Florida. 